\title{
FAKTOR-FAKTOR YANG BERHUBUNGAN DENGAN KELENGKAPAN DOKUMENTASI KEPERAWATAN
}

\author{
Noorkasiani, Gustina, R. Siti Maryam* \\ Jurusan Keperawatan, Prodi Keperawatan Persahabatan Poltekkes Kemenkes Jakarta III, Jakarta 13230, Indonesia \\ "E-mail:rdmaryam@yahoo.com
}

\begin{abstract}
Abstrak
Dokumentasi keperawatan merupakan bukti pencatatan dan pelaporan yang dimiliki perawat dalam melakukan catatan keperawatan yang berguna untuk kepentingan klien, perawat dan tim kesehatan dalam memberikan pelayanan kesehatan. Desain penelitian adalah survei analitik dengan pendekatan cross sectional. Sampel berjumlah 173 perawat dari 14 ruang rawat dan lembar observasi kelengkapan dokumentasi berjumlah 80 dokumen. Hasil penelitian menunjukkan bahwa pelaksanaan dokumentasi keperawatan dalam kriteria baik sebesar 47,4\% dan perawat yang melengkapi dokumentasi keperawatan sebesar 57,2\%. Sedangkan faktor yang paling berkontribusi secara bermakna dengan kelengkapan dokumentasi keperawatan adalah Ruang Dinas $(p=0,002 ; \alpha=0,05)$ setelah dikontrol oleh umur, jenis kelamin, tingkat pendidikan, dan tipe kelas ruangan. Diharapkan bidang perawatan dapat melengkapi dokumentasi keperawatan dengan format yang sama, memberi kesempatan perawat untuk melanjutkan kuliah dan mengikuti pelatihan askep serta bertukar informasi atau gagasan antar ruang rawat.
\end{abstract}

Kata kunci: dokumentasi, kelengkapan, ruang dinas keperawatan

\section{Abstract}

Factors Related to The Documentation Completeness of Nursing. Nursing documentation is proof of recording and reporting is owned nurses in nursing notes were useful to the interests of clients, nurses and health team in providing health services. The study design was an analytical survey with cross sectional approach. Amount of 173 samples taken in a total nurse of 14 ward and 80 observation sheets about completeness of documentation in nursing process. The results showed that the implementation of nursing documentation in good criterion of 47,4\% and nurses who complete the documentation of nursing at 57,2\%. The factors most significantly associated with completeness of nursing documentation is the ward $(p=0,002 ; \alpha=0,05)$ after controlled by age, sex, educational level, and class room type. Advice can be given to the field of nursing in hospital to complete the documentation nursing with the same format, allowing nurses to pursue graduate studies and follow nursing process training and exchange information or ideas between the ward.

Keywords: completeness, documentation, nursing ward

\section{Pendahuluan}

Pelaksanaan dokumentasi keperawatan merupakan salah satu alat ukur untuk mengetahui, memantau, dan menilai suatu pelayanan asuhan keperawatan yang dilakukan oleh rumah sakit (Fischbach, 1991). Dokumentasi keperawatan tidak hanya mencerminkan kualitas perawatan saja tetapi membuktikan pertanggunggugatan setiap tim keperawatan (Potter \& Perry, 2005). Oleh karena itu, jika kegiatan keperawatan tidak didokumentasikan dengan baik, akurat, obyektif, dan lengkap serta sesuai dengan standar asuhan keperawatan maka sulit untuk membuktikan bahwa tindakan keperawatan telah dilakukan dengan benar (Gillies, 2000; Carpenito, 1999).

Hasil penelitian mengenai kelengkapan dokumentasi keperawatan bervariasi tiap rumah sakit. Penelitian yang dilakukan Hartati, Handoyo, dan Anis (2001) didapatkan skor 58\%; penelitian yang dilakukan Soetisno dan Christophara (2000) didapatkan angka 60\%; penelitian yang dilakukan Gaos dan Keliat (2002) pada 3 ruangan di RSUP 
Persahabatan (Soka Atas, Soka Bawah dan Anggrek Bawah) ditemukan dokumentasi asuhan keperawatan mencapai $57,8 \%$; dan penelitian yang dilakukan Sumitra dan Savitri (2000) di RSUD Karawang didapatkan rata-rata kelengkapan pendokumentasian asuhan keperawatan mencapai $\pm 50 \%$. Hasil penelitian tersebut menunjukkan kelengkapan dokumentasi keperawatan belum memenuhi standar asuhan keperawatan Depkes yaitu $80 \%$ sehingga mencerminkan mutu pelayanan keperawatan yang masih rendah.

Keberhasilan pendokumentasian asuhan keperawatan sangat dipengaruhi oleh seorang perawat sebagai ujung tombak dalam memberikan asuhan keperawatan (Potter \& Perry, 2005). Menurut Gibson (1996) dalam Suratun (2008) bahwa faktor individu yang memengaruhi perilaku kerja antara lain umur, lama kerja, pendidikan, dan pelatihan. Produktivitas seorang pekerja menurun dengan bertambahnya umur, sedangkan lama kerja mempunyai hubungan yang positif terhadap produktivitas pekerjaan. Siagian (2002) menyatakan bahwa makin tinggi tingkat pendidikan seseorang makin besar keinginan untuk memanfaatkan pengetahuan dan keterampilan. Pelatihan merupakan bagian dari proses pendidikan untuk meningkatkan pengetahuan dan keterampilan (Notoatmodjo, 2003).

Dokumentasi dibutuhkan untuk keamanan pasien dan menjaga catatannya untuk tetap jelas, akurat, dan komprehensif menjadi bermanfaat bagi perawat dalam pekerjaan sehari-hari (Bjorvell, 2002 \& Owen, 2005). Hal ini didukung pula oleh pendapat Wang, Hailey, dan Yu (2011) yang menyatakan bahwa kualitas dokumentasi keperawatan menunjukkan pemberian perawatan yang baik melalui komunikasi yang efektif di antara perawat dan dengan pemberi perawatan yang lain seperti keluarga pasien. Bjorvell (2002) menyatakan dari hasil FGD perawat bahwa cara menuliskan dokumentasi keperawatan membuat mereka menjadi berpikir kritis dan berpikir dengan cara yang berbeda terkait pelayanan yang diberikan kepada pasiennya.

Hasil observasi awal dan wawancara terhadap dokumentasi keperawatan diketahui dan ditemukan beberapa dokumen yang tidak diisi dengan benar dan lengkap terutama pada evaluasi keperawatan. Penilaian terhadap kelengkapan dokumentasi keperawatan untuk ruangan yang memiliki cara pendokumentasian yang sama belum pernah dilakukan.

\section{Metode}

Desain penelitian yang digunakan adalah survei analitik yaitu survei yang mencoba menggali bagaimana dan mengapa fenomena terjadi dengan pendekatan cross sectional. Penelitian dilakukan di RS X, Jakarta pada Bulan September 2010 sampai dengan Februari 2011. Populasi dalam penelitian ini adalah seluruh perawat yang bekerja di RS X dan memenuhi kriteria inklusi dan eksklusi. Sampel pada penelitian ini adalah 173 perawat yang bekerja di RS X dan memenuhi kriteria inklusi yaitu semua perawat di 14 ruangan dinas yang memiliki format dokumentasi keperawatan yang sama (Ruang Rawat Bedah dan Penyakit Dalam) dan bersedia menjadi responden. Kriteria eksklusi dari penelitian ini adalah kepala ruangan dan wakil kepala ruangan. Analisis bivariat menggunakan uji kai kuadrat dan multivariat dengan regresi logistik.

Tabel 1. Karakteristik Responden Menurut Kelengkapan Dokumentasi Keperawatan

\begin{tabular}{lcc}
\hline Kelengkapan Dokumentasi Keperawatan & Jumlah & Persentase \\
\hline Kurang Lengkap & 74 & 42,8 \\
Lengkap & 99 & 57,2 \\
Total & 173 & 100 \\
\hline
\end{tabular}




\section{Hasil}

Hasil penelitian menunjukkan bahwa proporsi perawat yang dokumentasi keperawatannya lengkap lebih banyak $(57,2 \%)$ dibandingkan dengan proporsi perawat yang dokumentasi keperawatannya kurang lengkap $(42,8 \%)$ (lihat pada Tabel 1).

Tabel 2 menunjukkan bahwa dari 93 perawat yang berusia lebih dari hingga sama dengan 28 tahun, sebanyak 57 perawat $(61,3 \%)$ yang melakukan dokumentasi kepera-watan dengan lengkap. Hasil didapatkan bahwa dari 80 perawat yang berusia kurang dari 28 tahun, terdapat 42 perawat $(52,5 \%)$ yang dokumentasi kepera-watannya lengkap. Hasil penelitian juga didapatkan bahwa dari 11 perawat yang berpendidikan SPK, sebanyak empat perawat $(36,4 \%)$ yang melakukan dokumentasi keperawatan dengan lengkap. Selain itu, dari 162 perawat yang berpendidikan DIII Keperawatan, sebanyak 95 (58,6\%) perawat yang dokumentasi keperawatannya lengkap. Hasil juga menunjukkan bahwa dari 101 perawat yang bekerja kurang dari 5 Tahun, terdapat 59 perawat $(58,4 \%)$ yang dokumentasi keperawatannya lengkap. Dari 22 perawat yang bekerja selama 5-10 Tahun, sebanyak 10 perawat $(45,5 \%)$ yang dokumentasi keperawatannya lengkap. Dari 50 perawat yang bekerja lebih dari 10 tahun, sebanyak $30(60,0 \%)$ yang dokumentasi keperawatannya lengkap.

Hasil menunjukkan bahwa dari 114 perawat yang tidak pernah mengikuti pelatihan asuhan keperawatan, sebanyak 64 perawat $(56,1 \%)$ yang dokumentasi keperawatannya lengkap. Dari 59 perawat yang pernah mengikuti pelatihan, ada sebanyak 35 perawat $(59,3 \%)$ yang dokumentasi keperawatannya lengkap.

Hasil menunjukkan bahwa dari 84 perawat yang pengetahuan terkait dokumentasi keperawatannya rendah, sebanyak 49 perawat $(58,3 \%)$ yang dokumentasi keperawatannya lengkap. Dari 89 perawat yang pengetahuan dokumentasi keperawatannya tinggi hanya ada sebanyak 50 perawat $(56,2 \%)$ yang melakukan dokumentasi keperawatan dengan lengkap.

Tabel 2. Karakteristik Responden Menurut Usia, Tingkat Pendidikan, Lama Kerja, Mengikuti Pelatihan, Tingkat Pengetahuan, Pelaksanaan Dokumentasi Keperawatan, dan Kelengkapan Dokumentasi Keperawatan

\begin{tabular}{|c|c|c|c|c|c|c|}
\hline \multirow{3}{*}{ Variabel } & \multicolumn{4}{|c|}{ Kelengkapan Dokumentasi Keperawatan } & \multirow{2}{*}{\multicolumn{2}{|c|}{ Total }} \\
\hline & \multicolumn{2}{|c|}{ Kurang Lengkap } & \multicolumn{2}{|c|}{ Lengkap } & & \\
\hline & $\mathbf{n}$ & $\%$ & $\mathbf{N}$ & $\%$ & $\mathbf{N}$ & $\%$ \\
\hline \multicolumn{7}{|l|}{ Usia } \\
\hline$\geq 28$ Tahun & 36 & 38,7 & 57 & 61,3 & 93 & 100 \\
\hline$<28$ Tahun & 38 & 47,5 & 42 & 52,5 & 80 & 100 \\
\hline \multicolumn{7}{|l|}{ Tingkat Pendidikan } \\
\hline SPK & 7 & 63,6 & 4 & 36,4 & 11 & 100 \\
\hline DIII & 67 & 41,4 & 95 & 58,6 & 162 & 100 \\
\hline \multicolumn{7}{|l|}{ Lama Kerja } \\
\hline$<5$ Tahun & 42 & 41,6 & 59 & 58,4 & 101 & 100 \\
\hline 5-10 Tahun & 12 & 54,5 & 10 & 45,5 & 22 & 100 \\
\hline >10 Tahun & 20 & 40,0 & 30 & 60,0 & 50 & 100 \\
\hline \multicolumn{7}{|l|}{ Mengikuti Pelatihan } \\
\hline Tidak pernah & 50 & 43,9 & 64 & 56,1 & 114 & 100 \\
\hline Pernah & 24 & 40,7 & 35 & 59,3 & 59 & 100 \\
\hline \multicolumn{7}{|l|}{ Tingkat Pengetahuan } \\
\hline Rendah & 35 & 41,7 & 49 & 58,3 & 84 & 100 \\
\hline Tinggi & 39 & 43,8 & 50 & 56,2 & 89 & 100 \\
\hline \multicolumn{7}{|c|}{ Pelaksanaan Dokumentasi Keperawatan } \\
\hline Kurang baik & 41 & 45,1 & 50 & 54,9 & 91 & 100 \\
\hline Baik & 33 & 40,2 & 49 & 59,8 & 82 & 100 \\
\hline
\end{tabular}


Tabel 3. Karakteristik Responden Menurut Ruangan Dinas dan Kelengkapan Dokumentasi Keperawatan

\begin{tabular}{|c|c|c|c|c|c|c|c|}
\hline \multirow{3}{*}{ Ruangan Dinas } & \multicolumn{4}{|c|}{ Kelengkapan Dokumentasi Keperawatan } & \multirow{2}{*}{\multicolumn{2}{|c|}{ Total }} & \multirow{3}{*}{$\mathbf{p}$} \\
\hline & \multicolumn{2}{|c|}{ Kurang Lengkap } & \multicolumn{2}{|c|}{ Lengkap } & & & \\
\hline & $\mathbf{n}$ & $\%$ & $\mathbf{n}$ & $\%$ & $\mathbf{n}$ & $\%$ & \\
\hline Griya Puspa & 11 & 84,6 & 2 & 15,4 & 13 & 100 & 0,000 \\
\hline Mawar Atas & 15 & 100,0 & 0 & 00,0 & 15 & 100 & \\
\hline Mawar Bawah & 0 & 00,0 & 17 & 100,0 & 17 & 100 & \\
\hline Dahlia Atas & 6 & 60,0 & 4 & 40,0 & 10 & 100 & \\
\hline Dahlia Bawah & 0 & 00,0 & 9 & 100,0 & 9 & 100 & \\
\hline Melati Atas & 10 & 71,4 & 4 & 28,6 & 14 & 100 & \\
\hline Melati Bawah & 6 & 31,6 & 13 & 68,4 & 19 & 100 & \\
\hline Soka Atas & 7 & 50,0 & 7 & 50,0 & 14 & 100 & \\
\hline Soka Bawah & 4 & 36,4 & 7 & 63,6 & 11 & 100 & \\
\hline Cempaka Atas & 8 & 57,1 & 6 & 42,9 & 14 & 100 & \\
\hline Cempaka Bawah & 0 & 00,0 & 9 & 100,0 & 9 & 100 & \\
\hline Bedah Kelas & 4 & 33,3 & 8 & 66,7 & 12 & 100 & \\
\hline Anggrek Bawah & 1 & 12,5 & 7 & 87,5 & 8 & 100 & \\
\hline Bedah Thorax & 2 & 25,0 & 6 & 75,0 & 8 & 100 & \\
\hline Jumlah & 74 & 42,8 & 99 & 57,2 & 173 & 100 & \\
\hline
\end{tabular}

Tabel 4. Karakteristik Responden Menurut Tipe Kelas Ruangan dan Kelengkapan Dokumentasi Keperawatan

\begin{tabular}{|c|c|c|c|c|c|c|c|}
\hline \multirow{3}{*}{ Tipe Kelas } & \multicolumn{4}{|c|}{ Kelengkapan Dokumentasi Keperawatan } & \multirow{2}{*}{\multicolumn{2}{|c|}{ Total }} & \multirow{3}{*}{$\mathbf{p}$} \\
\hline & \multicolumn{2}{|c|}{ Kurang Lengkap } & \multicolumn{2}{|c|}{ Lengkap } & & & \\
\hline & $\mathbf{n}$ & $\%$ & $\mathbf{n}$ & $\%$ & $\mathbf{n}$ & $\%$ & \\
\hline Kelas I & 21 & 61,8 & 13 & 38,2 & 34 & 100 & 0,028 \\
\hline Kelas II & 18 & 50,0 & 18 & 50,0 & 36 & 100 & \\
\hline Kelas III & 24 & 33,3 & 48 & 66,7 & 72 & 100 & \\
\hline VIP & 11 & 35,5 & 20 & 64,5 & 31 & 100 & \\
\hline
\end{tabular}

Tabel 5. Hasil Pemodelan Terakhir Analisis Multivariat

\begin{tabular}{|c|c|c|c|c|}
\hline \multirow{2}{*}{ Variabel } & \multirow{2}{*}{$\mathbf{p}$} & \multirow{2}{*}{ OR } & \multicolumn{2}{|c|}{$95 \% \mathrm{CI}$} \\
\hline & & & Batas Bawah & Batas Atas \\
\hline Usia & 0,071 & 0,410 & 0,156 & 1,080 \\
\hline Jenis Kelamin & 0,126 & 0,324 & 0,076 & 1,375 \\
\hline Tingkat Pendidikan & 0,061 & 6,795 & 0,917 & 50,338 \\
\hline Ruang Dinas Melati Bawah & 0,002 & 24,183 & 3,370 & 173,51 \\
\hline Tipe Kelas Ruangan & 0,960 & 0,000 & 0,000 & - \\
\hline
\end{tabular}

Hasil menunjukkan bahwa dari 91 perawat yang kurang baik melaksanakan dokumentasi keperawatan, sebanyak 50 perawat $(54,9 \%)$ yang dokumentasi keperawatannya lengkap. Dari 82 perawat yang baik dalam pelaksanaan dokumentasi keperawatan, sebanyak 49 perawat
$(59,8 \%)$ yang dokumentasi keperawatannya lengkap.

Tabel 3 menunjukkan bahwa dari 14 ruangan dinas, ada 3 ruangan dimana perawatnya melengkapi dokumentasi keperawatan sebesar $100 \%$ yaitu ruang mawar bawah, dahlia bawah dan 
cempaka bawah. Sedangkan ruang griya puspa hanya sebanyak $15,4 \%$ yang dokumentasi keperawatan lengkap. Dari hasil analisis lebih lanjut dapat disimpulkan bahwa ada hubungan yang signifikan antara ruangan dinas perawat dengan kelengkapan dokumentasi keperawatan $(p=0,000 ; \alpha=0,05)$.

Tabel 4 menunjukkan bahwa dari 34 perawat yang dinas di ruangan kelas I, sebanyak 13 perawat $(38,2 \%)$ yang dokumentasi keperawatannya lengkap. Dari 36 perawat yang dinas di ruangan kelas II, ada sebanyak 18 perawat $(50,0 \%)$ yang dokumentasi keperawatannya lengkap. Dari 72 perawat yang dinas di ruangan kelas III, sebanyak 48 perawat $(66,7 \%)$ yang dokumentasi keperawatannya lengkap. Sejumlah 31 perawat yang dinas di ruangan VIP, sebanyak 20 perawat $(64,5 \%)$ yang dokumentasi keperawatannya lengkap. Dari hasil analisis lebih lanjut dapat disimpulkan bahwa ada hubungan yang signifikan antara tipe kelas ruangan dinas perawat dengan kelengkapan dokumentasi keperawatan $(p=0,028 ; \alpha=0,05)$.

Tabel 5 menunjukkan bahwa hasil analisis didapatkan nilai OR dari variabel Ruang Dinas Melati Bawah adalah 24,2 artinya perawat yang berada di Ruang Dinas Melati Bawah melakukan pendokumentasian keperawatan yang lebih lengkap dibandingkan ruangan lain setelah dikontrol variabel usia, jenis kelamin, tingkat pendidikan, dan tipe kelas ruangan $(\mathrm{p}=0,002$; $\alpha=0,05$ ). Ruang Dinas Melati Bawah paling besar pengaruhnya terhadap kelengkapan dokumentasi keperawatan.

\section{Pembahasan}

Kelengkapan Dokumentasi Keperawatan. Kelengkapan dokumentasi keperawatan di 14 ruang rawat inap RS X, Jakarta menunjukkan proporsi perawat yang pendokumentasian keperawatannya lengkap sebesar $57,2 \%$. Hal ini hampir sama dengan penelitian yang dilakukan Hartati, Handoyo, dan Anis (2001) didapatkan skor 58\%; penelitian yang dilakukan Soetisno dan Christophara (2000) didapatkan angka 60\%; penelitian yang dilakukan Gaos dan Keliat
(2002) pada 3 ruangan di RSUP Persahabatan (Soka Atas, Soka Bawah dan Anggrek Bawah) ditemukan dokumentasi asuhan keperawatan mencapai $57,8 \%$; dan penelitian yang dilakukan Sumitra dan Savitri (2000) di RSUD Karawang didapatkan rata-rata kelengkapan pendokumentasian asuhan keperawatan mencapai $\pm 50 \%$. Hasil penelitian di atas menunjukkan kelengkapan dokumentasi keperawatan belum memenuhi standar asuhan keperawatan Depkes yaitu 80\% sehingga mencerminkan mutu pelayanan keperawatan yang masih rendah.

Usia. Perawat yang berusia lebih dari hingga sama dengan 28 tahun melakukan pendokumentasian dengan lengkap sebesar $61,3 \%$ dibandingkan dengan perawat yang berusia kurang dari 28 tahun. Hal ini memperlihatkan bahwa hubungan antara umur dan kinerja merupakan isu penting, karena terdapat keyakinan bahwa kinerja akan merosot dengan bertambahnya umur (Robbin, 2006). Akan tetapi, hasil penelitian ini merubah keyakinan tersebut. Penelitian ini didukung pendapat Gibson (1996) dalam Suratun (2008) yang mengemukakan bahwa pekerja yang lebih tua dianggap lebih cakap secara teknis, lebih banyak pengalaman dan lebih bijaksana dalam pengambilan keputusan.

Tingkat Pendidikan. Hasil penelitian menunjukkan bahwa perawat yang berpendidikan DIII Keperawatan mendokumentasikan asuhan keperawatan lengkap sebesar $58,6 \%$ dibanding dengan SPK $(36,4 \%)$. Hal ini sesuai dengan pendapat Gibson (1996) dalam Suratun (2008) yang mengemukakan bahwa tingkat pendidikan yang tinggi umumnya menyebabkan seseorang lebih mampu dan bersedia menerima tanggung jawab. Sedangkan Siagian (2002) menjelaskan bahwa makin tinggi pendidikan seseorang makin besar keinginan untuk memanfaatkan pengetahuan dan keterampilan. Penelitian ini didukung pula oleh penelitian Fizran dan Mamdy (2002) yang mendapatkan bahwa tingkat pendidikan berhubungan secara bermakna dengan kinerja perawat dalam pendokumentasian keperawatan serta penelitian Usman dan Tafal (2002) yang mengemukakan bahwa tingkat 
pendidikan berhubungan secara bermakna dengan motivasi perawat dalam penerapan proses keperawatan.

Lama Kerja. Hasil penelitian didapatkan perawat yang bekerja lebih dari 10 Tahun melakukan pendokumentasian keperawatan dengan lengkap sebesar $60,0 \%$. Hal ini sesuai dengan pendapat Robbins (2006) dalam Suratun (2008) yang menyatakan terdapat suatu hubungan yang positif antara masa kerja dan produktifitas pekerjaan. Makin lama seseorang bekerja makin terampil dan berpengalaman melaksanakan pekerjaannya. Lama kerja menjadi sangat penting karena dapat mencerminkan tingkat kepuasan akhir yang dapat dicapai oleh karyawan. Hal ini didukung pula oleh penelitian Hotnida dan Sumiatun (2002) yaitu faktor lama kerja berpengaruh terhadap kinerja perawat dalam pendokumentasian proses keperawatan.

Ruang Dinas. Hasil penelitian dari 14 ruang dinas, ada 3 ruangan dengan perawat yang melengkapi dokumentasi keperawatan sebesar $100 \%$ yaitu Ruang Mawar Bawah (VIP), Dahlia Bawah (Kelas III), dan Cempaka Bawah (Kelas III). Sedangkan, Ruang Griya Puspa (VIP) hanya ada sebanyak $15,4 \%$ yang dokumentasi keperawatan lengkap. Dari hasil analisis lebih lanjut dapat disimpulkan bahwa ada hubungan yang signifikan antara ruangan dinas perawat dengan kelengkapan dokumentasi keperawatan $(p=0,000, \alpha=0,05)$. Asumsi peneliti menyatakan bahwa ruang dinas dan tipe kelas yang tinggi tidak selalu menunjukkan pendokumentasian keperawatannya lebih bagus dari ruang dinas dan tipe kelas yang lebih rendah.

Pelatihan. Hasil penelitian didapatkan bahwa perawat yang pernah mengikuti pelatihan akan melengkapi dokumentasi keperawatannya sebesar 59,3\% dibandingkan dengan perawat yang tidak pernah mengikuti pelatihan asuhan keperawatan. Penelitian ini sesuai dengan pendapat Notoatmodjo (2003) yang menyatakan pelatihan merupakan bagian dari proses pendidikan untuk peningkatan pengetahuan dan keterampilan kerja. Hal ini didukung oleh penelitian Fizran dan Mamdy (2002) yang mendapatkan bahwa pelatihan berhubungan secara bermakna dengan kinerja perawat dalam pendokumentasian keperawatan dan penelitian Soetisno dan Christophora (2000) yang menunjukkan bahwa ada pengaruh positif dari pelatihan pada kelengkapan dokumentasi keperawatan.

\section{Pengetahuan terkait Dokumentasi Kepera-} watan. Hasil penelitian menunjukkan perawat yang pengetahuannya terkait dokumentasi keperawatan rendah, ada sejumlah 58,3\% yang dokumentasi keperawatannya lengkap. Sedangkan perawat yang memiliki pengetahuan dokumentasi keperawatan tinggi, ada sebanyak $56,2 \%$ yang dokumentasi keperawatannya lengkap. Hal ini bertentangan dengan penelitian Fizran dan Mamdy (2002) yang mendapatkan bahwa tingkat pengetahuan berhubungan secara bermakna dengan kinerja perawat dalam pendokumentasian keperawatan. Begitu pula dengan penelitian Kusumawaty dan Yani (2001) yang mendapatkan bahwa adanya hubungan bermakna dan berpola positif antara pemahaman terhadap pendokumentasian proses keperawatan dengan kompetensi mendokumentasikan proses keperawatan. Asumsi peneliti menyatakan bahwa pengetahuan tinggi tidak selalu menunjukkan pelaksanaan dokumentasi keperawatan yang lengkap.

Pelaksanaan Dokumentasi Keperawatan. Hasil penelitian menunjukkan bahwa perawat yang baik dalam pelaksanaan dokumentasi keperawatan, ada sebanyak $59,8 \%$ perawat yang dokumentasi keperawatannya lengkap. Hal ini sesuai dengan pendapat Ali (2001) yang mengatakan bahwa penggunaan proses keperawatan sangat bermanfaat bagi pasien, perawat dan rumah sakit. Manfaat bagi pasien antara lain mendapat pelayanan keperawatan yang bermutu, efektif dan efisien; pasien bebas mengemukakan pendapat atau kebutuhannya demi proses kesembuhan; mendapatkan kepuasan dari pelayanan yang diberikan. Manfaat untuk perawat adalah mengembangkan kemampuan berpikir kritis maupun keterampilan teknis; meningkatkan kemandirian perawat dan meningkatkan citra perawat di mata masyarakat. Manfaat bagi rumah sakit adalah meningkatkan citra rumah sakit sehingga meningkatkan keuntungan bagi rumah sakit. 
Hasil penelitian didapatkan bahwa perawat yang berada di Ruang Dinas Melati Bawah pendokumentasian keperawatannya lebih lengkap dibandingkan ruangan lain setelah dikontrol variabel usia, jenis kelamin, tingkat pendidikan dan tipe kelas ruangan $(p=0,002 ; \alpha=0,05)$. Peneliti berasumsi karena Ruang Dinas Melati Bawah didukung dengan banyaknya jumlah perawat dibandingkan dengan ruangan lain dan penerapan metoda tim serta penggunaan format RM 6 yaitu format rekaman asuhan keperawatan yang hanya tinggal memberikan checklist dan menambah data atau rencana dari yang sudah ada.

\section{Kesimpulan}

Perawat yang dinas di Ruang Melati Bawah (Kelas I) menjadi faktor yang paling berhubungan dengan kelengkapan dokumentasi keperawatan setelah dikontrol oleh usia, jenis kelamin, tingkat pendidikan, dan tipe kelas ruangan. Perawat yang melaksanakan dokumentasi keperawatan dengan baik akan mendokumentasikan keperawatan dengan lengkap. Diharapkan bagi RS dapat menetapkan kebijakan terkait pelayanan keperawatan yang bermutu dengan meningkatkan kelengkapan dokumentasi keperawatan melalui bidang keperawatan dengan melengkapi format dokumentasi keperawatan dan aturan yang sama untuk setiap ruangan dan memberikan kesempatan pada perawat untuk mengikutsertakan atau mengadakan pelatihan terkait dokumentasi keperawatan dengan sistem komputerisasi. Bagi penelitian selanjutnya diharapkan dapat mengidentifikasi faktor lain yang berhubungan dengan kelengkapan dokumentasi keperawatan seperti supervisi, motivasi, pemberian reward dan punishment, jumlah ketenagaan perawat, beban kerja dan sebagainya (AS, RR).

\section{Referensi}

Ali, Z. (2001). Dasar-dasar keperawatan profesional. Jakarta: Penerbit EGC.

Bjorvell, C. (2002). Nursing documentation in clinical practice: Instrument development and evaluation of a comprehensive intervention programme. Stockholm Sweden: Karolinska Institutet.

Carpenito, L.J. (1999). Rencana asuhan keperawatan \& dokumentasi keperawatan, diagnosis keperawatan, dan masalah kolaborasi. Jakarta: Penerbit EGC.

Fischbach, F.T. (1991). Dokumenting care, communication, the nursing process, and documentation standards. Philadelphia: F.A.Davis Company.

Fizran, \& Mamdy, Z. (2002). Faktor-faktor yang berhubungan dengan kinerja perawat dalam pendokumentasian asuhan keperawatan di unit rawat inap RSUD Dr. Achmad Muchtar Bukittinggi (Tesis, Program Magister Fakultas Kesehatan Masyarakat UI). Fakultas Kesehatan Masyarakat UI, Jakarta.

Gaos, A.S., \& Keliat, B.A. (2002). Hubungan kelelahan kerja perawat pelaksana dengan dokumentasi asuhan keperawatan di ruang rawat RS Persahabatan. (Tesis magister, tidak dipublikasikan) Jakarta: FIK UI.

Gillies, D.A. (2000). Nursing management: A system approach. Philadelphia: Saunders Company.

Hotnida, L., \& Sumiatun (2002). Analisis faktorfaktor yang berpengaruh terhadap kinerja perawat dalam pendokumentasian proses keperawatan di ruang rawat inap RSUD Koja (Tesis magister, tidak dipublikasikan). Fakultas Kesehatan Masyarakat UI, Jakarta.

Kusumawaty, I., \& Yani, A. (2001). Hubungan antara pemahaman tentang proses keperawatan dan fungsi supervisi dengan kompetensi mendokumentasikan proses keperawatan di RS Karya Bhakti Bogor (Tesis magister, tidak dipublikasikan). Fakultas Ilmu Keperawatan UI, Jakarta.

Notoatmodjo, S. (2003). Pendidikan kesehatan masyarakat. Jakarta: Badan Penerbit Kesehatan Masyarakat FKM UI. 
Owen, K. (2005). Documentation in nursing practice. Nursing standard, 19 (32), 4849.

Potter, P.A., \& Perry, A.G. (2005). Buku ajar fundamental keperawatan: ajar fundamental keperawatan: Konsep, proses \& praktik. proses, \& praktik. (Alih Bahasa: Yasmin Asih, et al.,) (Edisi 4). Jakarta: Penerbit EGC.

Siagian, S.P. (2002). Manajemen sumber daya manusia. sumber daya manusia. Jakarta: Bumi Aksara.

Sumitra, \& Savitri, M. (2000). Faktor-faktor yang berhubungan dengan pelaksanaan dokumentasi pengkajian keperawatan oleh perawat di ruang rawat inap RSUD Karawang (Tesis magister, tidak dipublikasikan). Fakultas Kesehatan Masyarakat UI, Jakarta.

Suratun. (2008). Hubungan penerapan metode penugasan tim dengan kelengkapan dokumentasi asuhan keperawatan di RSUP Bekasi (Tesis magister, tidak dipublikasikan). Fakultas Ilmu Keperawatan UI, Jakarta.

Soetisno, B., \& Christophora, S. (2000). Pengaruh pelatihan perawat pada kelengkapan dokumentasi keperawatan di RS Imanuel (Tesis, Program Magister Fakultas Kesehatan Masyarakat UI). Fakultas Kesehatan Masyarakat UI, Jakarta.

Usman, S., \& Tafal, Z. (2002). Faktor-faktor yang memotivasi perawat dalam penerapan proses keperawatan di ruang rawat inap RS Zainoel Abidin Banda Aceh (Tesis, Program Magister Fakultas Kesehatan Masyarakat UI). Fakultas Kesehatan Masyarakat UI, Jakarta.

Wang, N., Hailey, D., \& Yu, P. (2011). Quality of nursing documentation and approaches to its evaluation: a mixed-method systematic review. Journal of Advanced Nursing, 67 (9), 1858-1875. doi: 10.1111/j.13652648.2011.05634.x 